As a preliminary demonstration project, funding limited the scope of variables that could be measured and reported here. Continued research of this type on a larger scale will help further define the potential benefits of a mob-rearing system and should include additional stress and infection measurements, such as white blood cell counts, neutrophil:lymphocyte ratios, and acute phase proteins.

B. Reed is Farm Advisor, UCCE Glenn County; C. Stull is Animal Welfare Specialist, Veterinary Medicine Extension, UC Davis; S.L. Berry is Dairy Extension Specialist and C. Batchelder is Graduate Student, Department of Animal Science, UC Davis.

The authors wish to thank the cooperating dairy farm and the Western Region Sustainable Agriculture Research and Education Program for funding support for this project. Statistical support was provided by Neil Willits, Ph.D., in the Division of Statistics, using SAS 6.12 (1995-96).

\section{Further reading}

Kung L, Demarco S, Siebenson LN, et al. 1997. An evaluation of two management sys tems for rearing calves fed milk replacer. $J$ Dairy Sci 80:2529-33.

McDonough SP, Stull CL, Osburn BI. 1994. Enteric pathogens in intensively reared veal calves. Am J Vet Res 55(11):1516-9.

Stull CL, McDonough SP. 1994. Multidisciplinary approach to evaluating welfare of veal calves in commercial facilities. J Anim Sci 72:2518-24.

Thurmond MC. 1986. Epidemiologic approaches used in a herd health practice to investigate neonatal calf mortality. Prev Vet Med 4:317-28.

USDA: APHIS: Veterinary Services, National Animal Health Monitoring System. 1996. Part II-C: Heifer Health. In Dairy '96, Part II: Changes in the U.S. Dairy Industry: 1991-1996. Fort Collins, CO: USDA APHIS Veterinary Service.

USDA: APHIS: Veterinary Services, National Animal Health Monitoring System. 1994. Part II: Dairy Heifer Morbidity, Mortality, and Health Management Focusing on Preweaned Heifers. National Dairy Heifer Evaluation Project. Fort Collins, CO: USDA Animal and Plant Inspection Service Veterinary Service.

USDA: APHIS: Veterinary Services, National Animal Health Monitoring System. 1993. Part I: Dairy Herd Management Practices Focusing on Preweaned Heifers. National Dairy Heifer Evaluation Project. Fort Collins, CO: USDA APHIS Veterinary Service.

\title{
Several fungicides control powdery mildew in peppers
}

\author{
Richard F. Smith $\square$ Steven T. Koike $\square$ Mike Davis \\ Krishna Subbarao $\square$ Frank Laemmlen
}

In the early 1990s, powdery mildew became a recurring problem on chili peppers and bell peppers in all production districts in California. Growers were initially unprepared to deal with the disease. Research has shown that several fungicides can control this disease. Sulfur is most effective as a preventive fungicide. In variety trials, four experimental varieties were significantly less susceptible to powdery mildew than the standard commercial variety. Genetic resistance is likely to eventually be incorporated into commercial bell pepper varieties.

Powdery mildew infects many crops, ornamentals and weeds commonly found in California. The pathogen is able to infect 710 host species from 59 plant families, and has been recorded around the world. It was noted on bell peppers in Israel in the 1950s, but did not occur on bell peppers in the United States until 1976, when it appeared in Florida. In 1983 it appeared in California in the Santa Clara Valley. The disease was not a production problem in California until 1992, when it infected numerous fields in the coastal production districts from San Benito County to Ventura County and caused losses of up to $50 \%$ to $60 \%$. After 1992 , pepper powdery mildew spread to the San Joaquin Valley and the desert production districts, and now it can be found in all major pepper production areas of the state.

Leveillula taurica (= Oidiopsis taurica) is unique among powdery mildews because of its internal growth habit. The fungal hyphae grow inside the host tissue, rather than on the surface of the leaf tissue, as is common with powdery mildews that infect most other plants. The fungus typically infects the older leaves first and can be seen with the naked eye when masses of the spore-bearing structures (conidiophores) extend out of the leaf tissue and appear as typical white, fuzzy powdery mildew growth.

The conidiophores are most often seen on the under sides of pepper leaves; however, when infection is severe, they can also be observed on the upper sides of the leaves. The spores of pepper powdery mildew, unlike most other powdery mildew types, contain sufficient water for growth, and as a result can germinate at relatively low humidities. For instance, they can germinate at relative humidities of $40 \%$ to $90 \%$, with the optimum being $90 \%$. The additional water that the spores contain makes them susceptible to bursting in the presence of free water in the environment from sources such as rain or sprinkler irrigation.

Pepper powdery mildew is typically observed at first harvest. However, during years of severe infection, it may be seen earlier in the growth cycle. If left uncontrolled, powdery mildew can affect a majority of the leaves on the plant. Severe infection causes yellowing of the leaves and subsequent defoliation of the plant, exposing pepper fruit to sunburn damage. Losses from sunburned fruit can range from $50 \%$ to $60 \%$.

Pepper powdery mildew is an ongoing problem in the coastal production districts because of favorable humidities and temperatures. However, in years with favorable weather conditions, the disease can cause significant damage in all pepper production districts, including the desert and San Joaquin Valley. This disease caused particularly severe losses in the early 


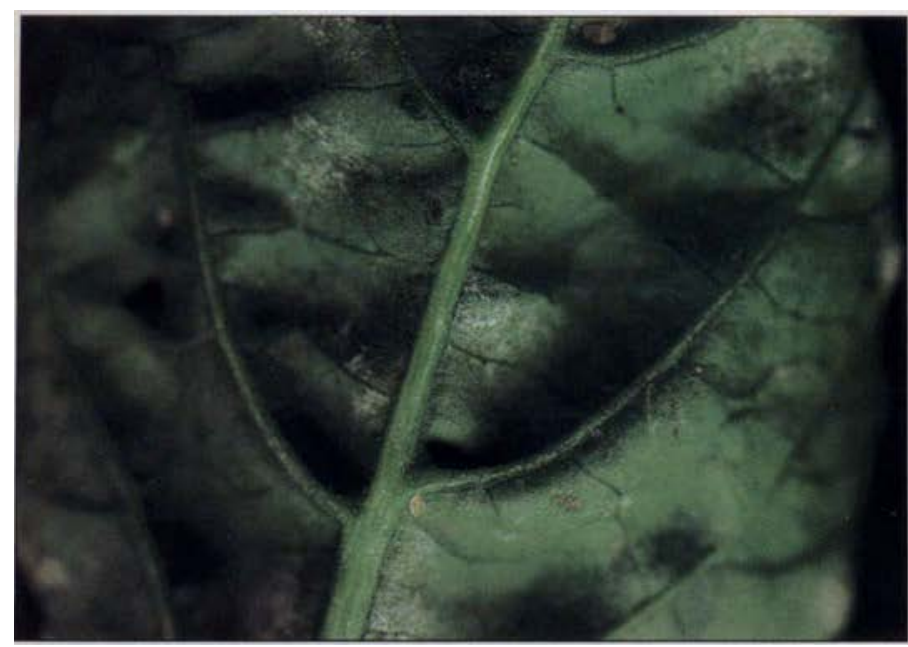

This close-up of the underside of a bell pepper leaf shows initial sporulation of pepper powdery mildew.

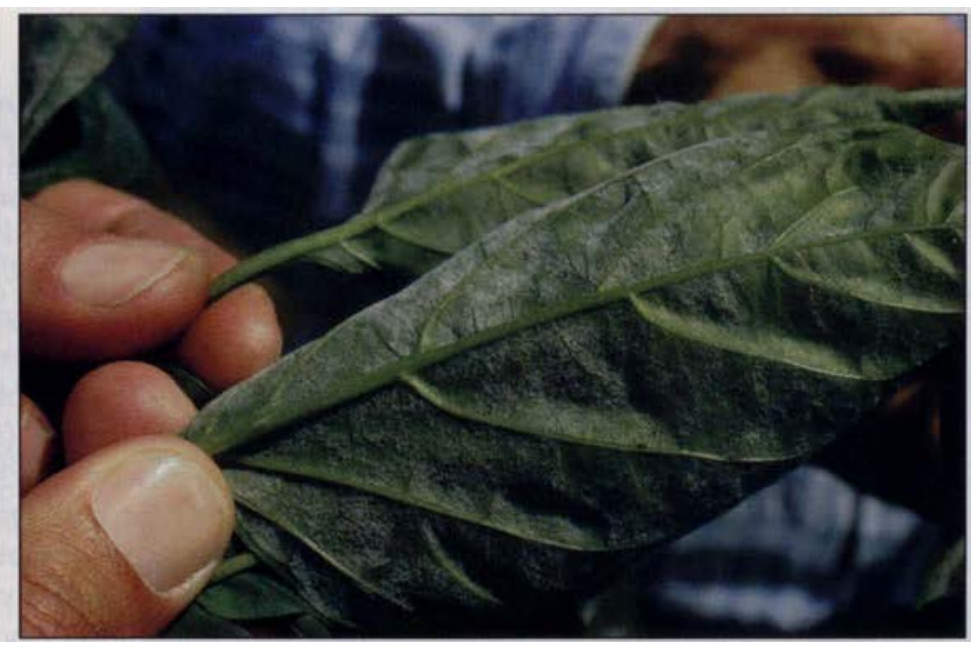

The undersides of these bell pepper leaves show extensive sporulation of pepper powdery mildew. years of the epidemic, when growers and crop consultants were unprepared. In 1992, we responded to the problem by initiating trials to identify fungicides that can effectively control the disease. A collaborative effort between the university, growers and the agricultural chemical industry resulted in an emergency registration for a fungicide that controlled the dis- ease. Since that time, we have continued to evaluate the efficacy of fungicides, as well as varietal resistance to the disease.

\section{Fungicide control trials}

We established trials in commercial pepper fields to test the efficacy of sulfur and other fungicide materials.

Each treatment was 3 beds wide and

\begin{tabular}{|c|c|c|c|c|c|}
\hline \multirow{2}{*}{$\begin{array}{l}\text { Treatment, rate/ac } \\
\text { (no. applications) }\end{array}$} & \multicolumn{4}{|c|}{ Disease ratings* } & \multirow{2}{*}{$\begin{array}{l}\text { Sunburned } \\
\text { fruit (1993) }\end{array}$} \\
\hline & $9 / 25 / 92$ & $10 / 6 / 92$ & $9 / 20 / 93$ & $9 / 29 / 93$ & \\
\hline & & & & & $\mathrm{lb} / \mathrm{plot}$ \\
\hline Triadimefon $4 \mathrm{oz}(3)$ & 1.5 & 0.7 & 0.2 & 0.1 & 8.3 \\
\hline Triadimefon $4 \mathrm{oz}(2)$ & 1.7 & 1.0 & 0.2 & 0.1 & 9.3 \\
\hline Myclobutanil 4 oz (3) & - & - & 0.1 & 0.2 & 6.8 \\
\hline Myclobutanil 4 oz (2) & - & - & 0.3 & 0.1 & 7.0 \\
\hline Sulfur $5 \mathrm{lb}(3)$ & 2.8 & 3.0 & 1.3 & 1.6 & 18.8 \\
\hline $\begin{array}{l}\text { Potassium bicarbonate } 0.5 \%(\mathrm{w} / \mathrm{v}) \\
+ \text { SunSpray Oil } 0.5 \%(\mathrm{w} / \mathrm{v})(3)\end{array}$ & 2.8 & 2.5 & - & - & - \\
\hline Control & 3.1 & 3.4 & 2.3 & 3.0 & 24.0 \\
\hline $\operatorname{LSD}(P=0.05)$ & 1.0 & 1.4 & 0.8 & 0.8 & 8.1 \\
\hline
\end{tabular}

"Foliar ratings: $0=0 \% ; 1=1 \%-10 \% ; 2=11 \%-25 \% ; 3=26 \%-50 \% ; 4=51 \%-75 \% ; 5=76 \%-100 \%$ of the leaf covered by powdery mildew.

TABLE 2. Disease ratings of the various fungicide treatments on three dates, 1996

\begin{tabular}{|c|c|c|c|}
\hline \multirow[b]{2}{*}{ Treatment, rate/ac (no. applications) } & \multicolumn{3}{|c|}{ Disease ratings* } \\
\hline & Sept 27 & Oct 10 & Oct 23 \\
\hline Sulfur $1 \mathrm{lb}(2)$ & 0.16 & 1.11 & 1.83 \\
\hline Sulfur $1 \mathrm{lb}(4)$ & 0.04 & 0.50 & 1.60 \\
\hline Sulfur $1 \mathrm{lb}(6)$ & 0.02 & 0.21 & 0.77 \\
\hline Sulfur $3 \mathrm{lb}(2)$ & 0.15 & 0.77 & 1.83 \\
\hline Sulfur $3 \mathrm{lb}(4)$ & 0.00 & 0.37 & 1.43 \\
\hline Sulfur $3 \mathrm{lb}(6)$ & 0.00 & 0.03 & 0.67 \\
\hline Sulfur $5 \mathrm{lb}(2)$ & 0.10 & 0.81 & 1.73 \\
\hline Sulfur $5 \mathrm{lb}(4)$ & 0.00 & 0.09 & 0.40 \\
\hline Trilogy $(0.5 \%$ v/v) $(6)$ & 0.35 & 1.01 & 1.67 \\
\hline Azoxystrobin $1.5 \mathrm{lb}(2)$ & 0.16 & 0.00 & 0.17 \\
\hline Triadimefon $4 \mathrm{oz}(1)$ & 0.03 & 0.04 & 0.57 \\
\hline Myclobutanil 4 oz (1) & 0.00 & 0.02 & 0.37 \\
\hline Propiconazole 4 oz (2) & 0.26 & 0.00 & 0.00 \\
\hline Control & 0.37 & 1.19 & 2.17 \\
\hline $\operatorname{LSD}(P=0.05)$ & 0.17 & 0.33 & 0.49 \\
\hline
\end{tabular}

"Foliar ratings: $0=0 \% ; 1=1 \%-10 \% ; 2=11 \%-25 \% ; 3=26 \%-50 \% ; 4=51 \%-75 \% ; 5=76 \%-100 \%$ of the leaf covered by powdery mildew.

25 feet long. All fungicides were applied with a $\mathrm{CO}_{2}$ backpack sprayer using four 8005 nozzles directed over the top and to the sides of the plants. All disease ratings and yield evaluations were taken from the middle row of each plot. Fungicide treatments were initiated at early flowering. All treatments were replicated four times in a randomized complete block design.

\section{Sulfur better as preventive}

Sulfur applied after the onset of pepper powdery mildew in 1992 and 1993 did not provide satisfactory control of this disease (table 1). Sulfur is a better preventive fungicide, and beginning in 1994 we conducted a series of trials to evaluate the efficacy of sulfur applications initiated at the early flowering stage, prior to the onset of mildew. Trials conducted in 1994 and 1995 showed that five or eight applications, respectively, of 5 pounds of sulfur per acre, applied on a 10-day spray application schedule, provided significantly greater control of pepper powdery mildew than did the untreated controls (data not shown). In 1996, we expanded the range of sulfur rates and timing intervals. Lower rates of sulfur, 1 and 3 pounds per acre, provided comparable control (table 2). At these low rates, however, six applications applied at 10-day spray intervals were necessary to obtain acceptable control over the entire season. At the higher rate of 5 pounds of sulfur per acre, four applications provided control that was comparable to six applications of the lower rates. 


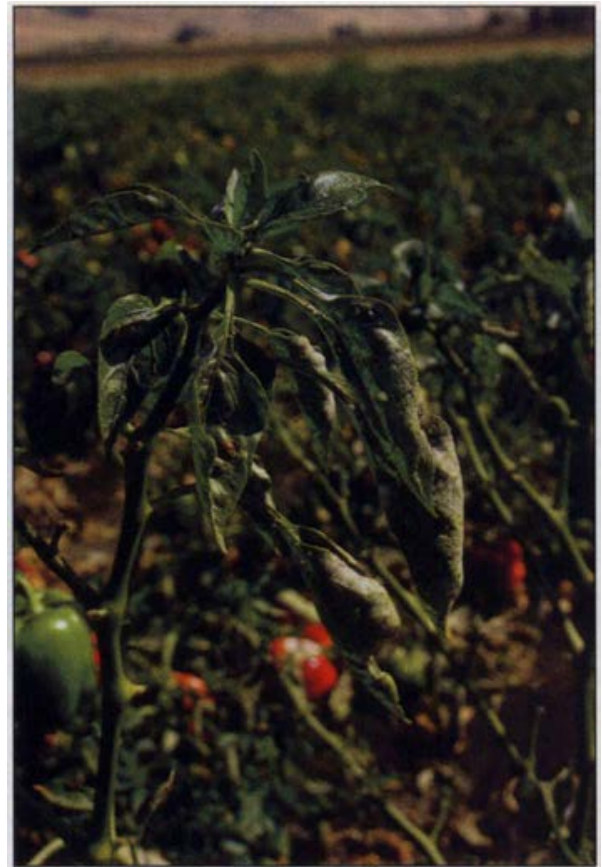

This plant shows extensive defoliation. Only young, less severely infected leaves remain on the plant.

In spite of the efficacy of sulfur, there are limitations to its use. Sulfur can be phytotoxic at temperatures above $90^{\circ} \mathrm{F}$, limiting its use in many pepper production districts. In addition, sulfur is not a systemic fungicide, and proper spray coverage is required to obtain satisfactory control of pepper powdery mildew.

Ground sprays typically provide adequate coverage because they use high pressure and volumes of water to apply the material. Under typical planting configurations, it is difficult to use ground rigs later in the season because the plant canopy closes over the furrows shortly after fruit set. As a result, growers rely on aerial applications to apply sulfur later in the season. However, there is uncertainty regarding the efficacy of aerial applications of sulfur on pepper powdery mildew because of reduced pressures and lower water volumes used in aerial applications ( 5 to 10 gallons of water/acre by air vs. 25 to 50 gallons of water/acre by ground rig). To answer the question of whether aerial applications could provide satisfactory control of pepper powdery mildew, we conducted a trial in 1997 simulating aerial applications of sulfur. We made six applications of 5 pounds of sulfur in 5 gallons of water at 10 psi. Powdery mildew control was good early in the season; however, control declined to unacceptable levels later in the season (table 3 ).

\section{Other fungicides more effective}

Triadimefon (Bayleton) and myclobutanil (Rally) provided excellent control of powdery mildew in all of the fungicide trials conducted from 1992 to 1997 (tables 1,2 and 3). These materials controlled the disease with only one or two applications of 4 ounces of material per acre, even after the onset of symptoms. Triadimefon was available for growers under an emergency Section 18 from 1992 to 1996. Beginning in 1997, myclobutanil was available to pepper growers under a Section 18 registration, and currently a full registration is being pur- sued with assistance from the Federal IR-4 program.

We also evaluated other powdery mildew control materials (tables 1, 2 and 3).

Bicarbonate materials are active on several species of powdery mildew. However, ammonium and potassium bicarbonates had limited efficacy on pepper powdery mildew and also caused phytotoxic effects such as brittleness of the leaves and marginal leaf burn.

Light plant oils coat the plant and reduce invasion of the plant tissue by germinating spores. We evaluated two oils, JMS Stylet Oil and two formulations of Trilogy (an extract of the neem tree seed). JMS Stylet Oil had limited efficacy and caused necrotic spots on the foliage. Trilogy provided limited control of pepper powdery mildew early in the season, but control quickly declined to unacceptable levels by midseason.

AQ-10 is a fungus (Ampelomyces quisqualis) that parasitizes and kills powdery mildew. Applications of this material provided limited control early in the season, but efficacy quickly declined.

Azoxystrobin (Quadris) and triflumizole (Procure) provided intermediate control of the pepper powdery mildew, while tebuconazole (Folicur) and propiconazole (Tilt) provided excellent control of the disease. However these four materials are not currently registered on peppers in California.

TABLE 3. Disease ratings and yield evaluations of various fungicide treatments, 1997

\begin{tabular}{|c|c|c|c|c|c|c|c|c|c|}
\hline \multirow{2}{*}{$\begin{array}{l}\text { Treatment, rate/ac } \\
\text { (no. applications) }\end{array}$} & \multicolumn{3}{|c|}{ Disease ratings* } & \multicolumn{4}{|c|}{ Yield $t$} & \multirow[b]{2}{*}{$\%$ Sunburn } & \multirow[b]{2}{*}{ Canopy $\neq$} \\
\hline & Sept 10 & Sept 23 & Oct 8 & Large & Small & Total & Sunburn & & \\
\hline & & & & & 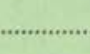 & & $\ldots$ & & \\
\hline Myclobutanil $4 \mathrm{oz}$ (2) & 0.03 & 0.01 & 0.02 & 18.1 & 14.4 & 32.5 & 7.5 & 19.0 & 9.5 \\
\hline Tebuconazole 8 oz (2) & 0.36 & 0.14 & 0.09 & 17.1 & 13.5 & 30.6 & 9.6 & 23.9 & 9.1 \\
\hline Azoxystrobin $15.4 \mathrm{oz}(3)$ & 0.23 & 0.94 & 1.34 & 16.3 & 12.7 & 28.9 & 7.4 & 20.9 & 7.5 \\
\hline Propiconazole 8 oz (2) & 0.61 & 0.16 & 0.04 & 15.9 & 13.2 & 29.1 & 7.2 & 19.8 & 9.1 \\
\hline Sulfur $5 \mathrm{lb}(6)$ & 0.05 & 0.30 & 1.65 & 16.7 & 15.5 & 32.3 & 6.9 & 17.5 & 8.0 \\
\hline$A Q-1010 z(6)$ & 0.95 & 2.80 & 4.10 & 9.3 & 13.7 & 23.1 & 9.9 & 31.0 & 2.0 \\
\hline Trilogy $701 \%$ v/v (6) & 0.87 & 2.28 & 3.22 & 11.6 & 12.2 & 23.7 & 9.4 & 28.7 & 5.0 \\
\hline Trilogy $702 \%$ v/v (6) & 0.61 & 2.33 & 3.20 & 9.6 & 14.5 & 24.1 & 8.8 & 26.1 & 4.8 \\
\hline Trilogy $901 \%$ v/v (6) & 0.61 & 2.73 & 3.75 & 15.8 & 11.5 & 27.3 & 9.2 & 25.6 & 3.3 \\
\hline Control & 2.28 & 4.35 & 4.70 & 11.1 & 12.9 & 24.0 & 9.0 & 27.8 & 1.5 \\
\hline $\operatorname{LSD}(P=0.05)$ & 0.42 & 0.99 & 0.62 & 8.5 & 3.7 & 9.1 & 4.9 & 12.9 & 0.9 \\
\hline
\end{tabular}

"Foliar ratings: $0=0 \% ; 1=1 \%-10 \% ; 2=11 \%-25 \% ; 3=26 \%-50 \% ; 4=51 \%-75 \% ; 5=76 \%-100 \%$ of the leaf covered by powdery mildew tRed fruit from 15 plants from the middle of the center row of the plot

$\ddagger$ Visual rating of the condition of the canopy: $0=$ complete defoliation; $10=$ completely healthy 


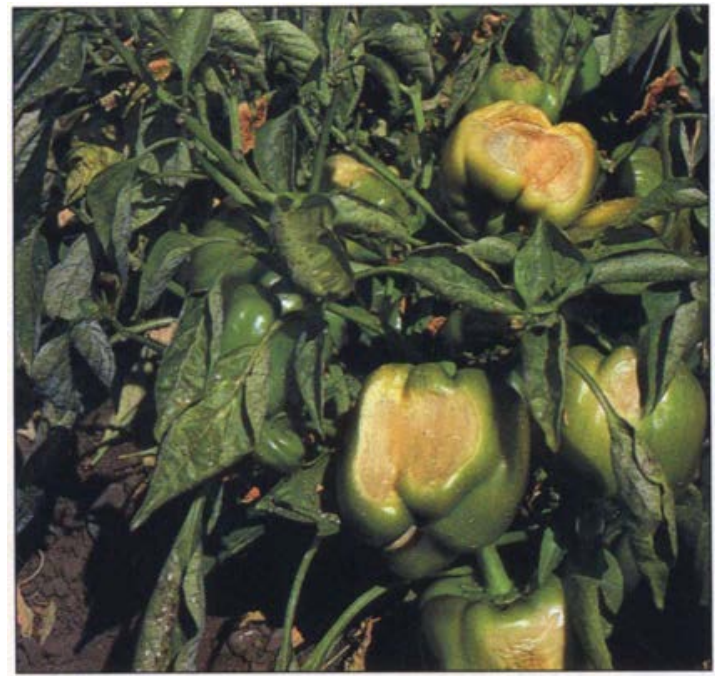

\section{Varietal resistance}

Resistance to pepper powdery mildew exists in peppers. From 1992 to 1997, we conducted trials on 20 footlong replicated strips of commercial, as well as experimental, lines of peppers. No commercially available varieties of bell peppers were found to be resistant to powdery mildew, but there were differences in varietal susceptibility. For example, yellow bell and lamuyo peppers are extremely susceptible to powdery mildew and defoliate under slight infections. Green bell pepper varieties are intermediate in susceptibility, while most varieties of jalapeno peppers can withstand heavy infections before defoliation occurs. Our 1995 trial included two "wild type" peppers - PI 152225 and PI 159236 - that were shown to be resistant to the disease. HV-12 is a longpodded sweet pepper from France that is also resistant to powdery mildew. Variety 94-128, a hybrid cross between HV-12 and a commercial bell pepper line, was slightly susceptible to pepper powdery mildew. All four of these varieties had significantly less powdery mildew than the standard commercial variety, D-93, that was included in the trial $(P<0.05)$. However, the field resistance that we observed in this trial has not been substantiated in greenhouse evaluations conducted by commercial seed companies.

Seed companies are continuing to evaluate these varieties, as well as others, for effective sources of resistance to pepper powdery mildew. It is hoped that in the near future resis-
This green bell pepper field shows sunburned fruit.

The furrows are full of leaves that have fallen from the plants due to defoliation from pepper powdery mildew.

4 Close-up of sunburned fruit due to defoliation from pepper powdery mildew.

tance to powdery mildew will be bred into commercial pepper varieties, which will offer growers additional options to combat this serious production problem.

\section{Powdery mildew is controllable}

Pepper powdery mildew became a serious threat to the California pepper industry in 1992. Sulfur can provide reasonable control of pepper

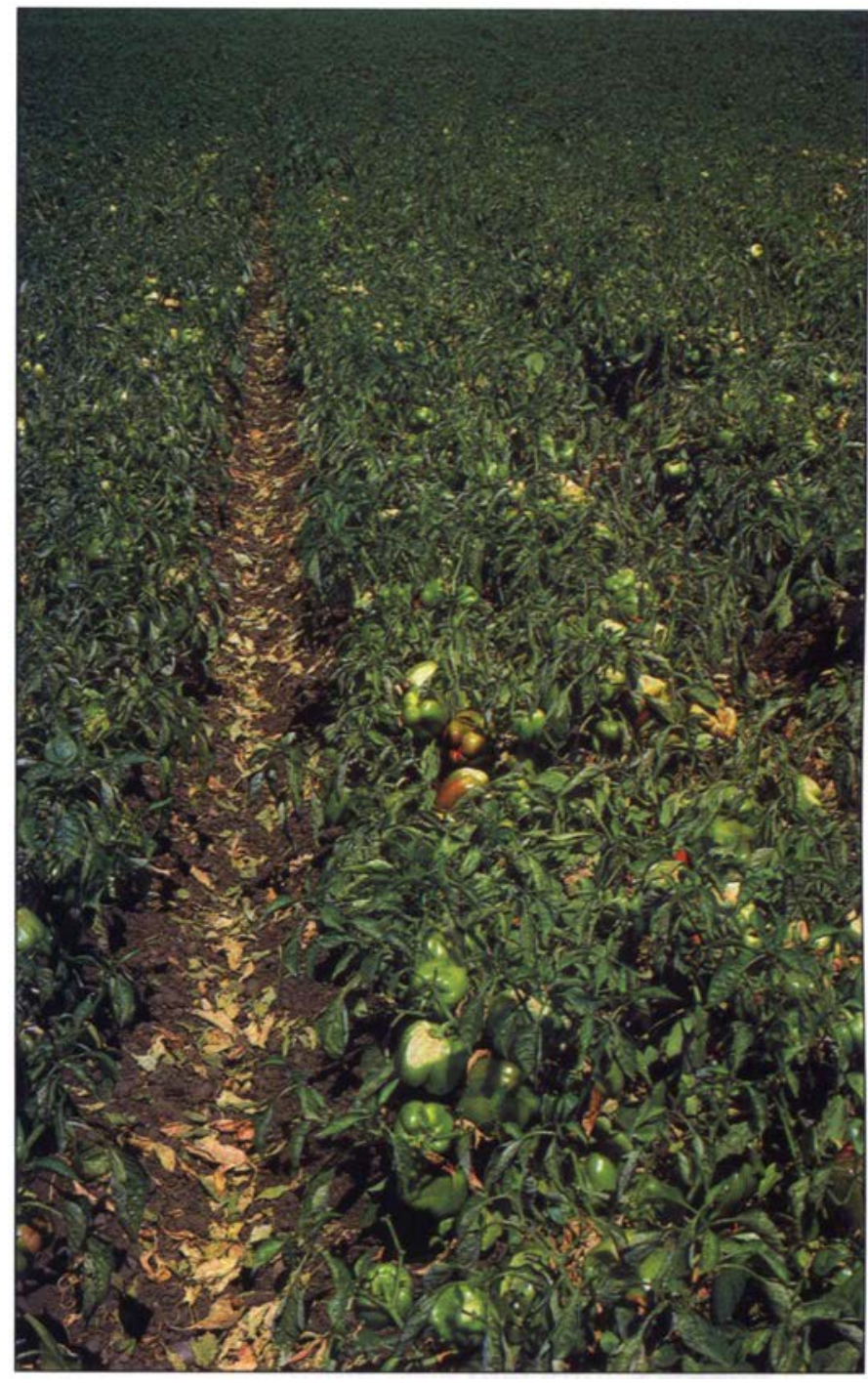
powdery mildew if it is applied prior to the onset of the disease and at frequent intervals. Good coverage is required for effective control with this material. Sulfur is the principal method that organic growers use to control pepper powdery mildew. However, the issues of application, temperature restrictions and possible crop injury make the use of sulfur a less desirable and difficult option for many growers in California. Careful monitoring of the disease and the effective use of fungicide programs can provide acceptable control of pepper powdery mildew. Varietal resistance to this disease will eventually be incorporated into commercial cultivars of peppers, which will provide growers with further options.

R.F. Smith and S.T. Koike are Farm Advisors, Monterey County; M. Davis and K. Subbarao are Extension Plant Pathologists, Department of Plant Pathology, UC
Davis; F. Laemmlen is Farm Advisor, Santa Barbara County.

The authors thank the cooperating growers and crop consultants, as well as the California Pepper Commission, for their support of this research.

\section{Further reading}

Blazquez, $\mathrm{CH}$. 1976. A powdery mildew of chilli caused by Oidiopsis sp. Phytopathology 66:1155-7.

Correll JC, Gordon TR, Elliott VJ. 1987. Host range, specificity, and biometical measurements of Leveillula taurica in California. Plant Disease 71:248-51.

Hartz TK, LeStrange M, Mayberry K, Smith RF. 1996. Bell Pepper Production in California. Vegetable Research and Information Center, Vegetable Production Series. DANR Publication 7217.

Reuveni R, Rotem J. 1973. Epidemics of Leveillula taurica on tomatoes and peppers as affected by the conditions of humidity. Phytopathology 76:153-7.

Smith RF, Laemmlen F, Koike ST, Subbarao K. 1998. Strategies to control powdery mildew, Pepper News 6:4. 